\title{
Література
}

1. Методика навчання української мови в початковій школі: навчальнометодичний посібник [для студентів вищих навчальних закладів]/ за наук. ред. М. С. Вашуленка. - К. : Літера ЛТД, 2010. - 364 с. 2. Державний стандарт початкової загальної освіти для дітей з особливими освітніми потребами [Електронний ресурс]. Режим доступу: http://zakon3.rada.gov.ua/laws/show/607-2013- \%D0 \%BF 3. Концепція мовної освіти в Україні [Електронний ресурс].- Режим доступу: http://chervonakalina.ucoz.com/load/osvita/koncepciji/koncepcija_movnoji_osviti_v_ukraji ni/6-1-0-74. 4. Навчальні програми для підготовчого, 1-4 класів спеціальних загальноосвітніх навчальних закладів для дітей з тяжкими порушення мовлення / Л. І. Трофименко. - К., 2014 p. [Електронний ресурс]. - Режим доступу : http://www.mon.gov.ua/ua/activity/education/56/693/navchalni_programi11

5. Олефір О. І. Напрями лексичної роботи 3 молодшими школярами із тяжкими порушеннями мовлення на уроках читання [Електронний ресурс]. - Режим доступу: http://www.logopedu.com.ua/article/432_Napryami_leksichnoi_roboti_z_molodshimi_shkol yarami_iz_tyajkimi_movlennevimi_vadami_na_yrokah_chitannya. 6. Ушинський К. Д. О первоначальном преподавании русского языка / К. Д. Ушинський // Избр. пед. соч. M., 1954. - T. 2. - C. 689.

Ольга Бондаренко

\section{ЗМІСТ, ФОРМИ І МЕТОДИ ПРОФОРІЕНТАЦІЙНОЇ РОБОТИ В УМОВАХ ПРОФІЛЬНОЇ ШКОЛИ}

Бондаренко О. В. Зміст, форми і методи профорієнтаційної роботи в умовах профільної школи.

У статті висвітлено зміст професійної спрямованості старшокласників, розглянуто форми й методи їі формування. На основі теоретичного узагальнення й вивчення практичного стану проблеми, автором виявлено чинники, що впливають на результативність профорієнтаційної роботи в умовах профільної школи.

Ключові слова: професійна спрямованість, професійне самовизначення, профільне навчання, профільна школа, профорієнтаційна робота.

Бондаренко О. В. Содержание, формы и методы профориентационной работы в условиях профильной школы.

В статье освещено содержание профессиональной направленности старшеклассников, рассмотрены формы и методы ее формирования. На основе теоретического обобщения и изучения практического состояния проблемы, автором выявлены факторы, влияющие на результативность профориентационной работы в условиях профильной школы.

Ключевые слова: профессиональная направленность, профессиональное самоопределение, профильное обучение, профильная школа, профориентационная работа.

Bondarenko O. V. Content, forms and methods of forming professional orientation of high school students in terms of specialized schools.

In the article the content of professional orientation seniors are considered forms and methods of formation. Based on the theoretical study and practical generalization of the 
problem, the author identified the factors that affect performance career-oriented work in specialized schools.

Key words: professional orientation, professional self-profile training, profile school, career-oriented work.

Нині характерною тенденцією розвитку загальноосвітньої школи є відмова від уніфікованості й одноманітності, які були традиційними для неї кілька століть [9]. Це означає, відмову від стандартизованих навчального змісту, форм і методів організації навчально-виховного процесу, й переорієнтацію на особистісно зорієнтовані, тобто такі, реалізація яких забезпечить розкриття особистісного потенціалу кожного старшокласника й формування в нього спрямованості на майбутню професію. Потенційні можливості у формуванні професійної спрямованості майбутніх старшокласників має саме профільна школа.

Аналіз наукової літератури свідчить, що окремі аспекти досліджуваної проблеми знайшли відображення в працях, присвячених профільному навчанню, яке досліджувалося у працях вітчизняних та російських науковців: Н. Аніскіної, Н. Бібік, М. Гузика, О. Савченко, Н. Шиян.

Зацікавлення в плані розв'язання обраної проблеми викликають наукові праці, присвячені психологічним особливостям професійної орієнтації учнів (Б. Ананьєв, Л. Божович, Ю. Гільбух, Г. Костюк, Л. Потапюк, К. Сазонов); соціально-педагогічним чинникам професійного самовизначення особистості (І. Назімов, В. Савченко, Г. Чередниченко).

Однак, аналіз стану досліджуваної проблеми в педагогічній теорії та практиці доводить, що існують суперечності між потребами суспільства у фахівцях з високим рівнем професіоналізму, здатних до постійного саморозвитку та самовдосконалення та несформованістю професійної спрямованості у більшості випускників загальноосвітніх шкіл; соціально-педагогічними вимогами свідомого і самостійного вибору професії і недостатньою інформованістю підростаючого покоління про складний світ професій та потреби ринку праці; об'єктивною потребою особистості у професійному самовизначенні й невідповідністю форм і методів профорієнтаційної роботи соціально-економічним вимогам суспільства.

Mema cmammi- розкрити зміст, форми й методи формування професійної спрямованості старшокласників в умовах профільної школи.

У науковій літературі професійна спрямованість найчастіше визначається як особистісна характеристика, яка виявляється в активному стійкому прагненні займатися певною професійною діяльністю, вдосконалюватися в ній $[1 ; 2 ; 3]$.

Провідна роль у створенні умов для професійного самовизначення учнів належить саме профорієнтаційній роботі, яка є невід'ємним складником навчальновиховного процесу. Однак, як слушно зазначає О. Браташ, нині «учнів не орієнтують на вибір тієї або іншої спеціальності» [2]. Наслідком такої ситуації $\epsilon$ «незбалансованість спеціальностей і відірваність знань, отриманих у ВНЗ, від потреб працедавців» [2], недотримання принципу соціальної рівноваги.

У «Концепції профільного навчання у старшій школі» зазначається, що реалізація принципу соціальної рівноваги передбачає узгодження трьох позицій: можливостей освітніх послуг, запитів ринку праці й соціальних очікувань випускників школи [4].

Науковці (О. Браташ [2], С. Мантуленко [5], Н. Побірченко [6] та ін.) стверджують, що вибір старшокласником майбутньої професії залежить від рівня організації профорієнтаційної роботи в школі, допрофільної та профільної підготовки. 
До основних чинників, що утруднюють організацію профорієнтаційної роботи в школі науковці відносять: недостатність методичної літератури 3 означеної проблематики, домінування серед профінформаційних форм бесід і зустрічей зі спеціалістами й практично повна відсутність такої форми, як «професійні проби» [3, c. 178], недостатня адаптація змісту шкільної освіти до потреб старшокласників тощо.

Водночас, «учитель профільної школи повинен забезпечувати проектування індивідуальних освітніх траєкторій, використання проектно-дослідницьких і комунікативних методів, формування компетентностей, необхідних для продовження освіти у відповідній сфері професійної освіти» [1, с. 69].

На основі аналізу наукової літератури та вивчення педагогічного досвіду 3 досліджуваної проблеми, доцільно виокремити такі форми та методи формування професійної спрямованості старшокласників в умовах профільної школи:

- профінформаційні та профорієнтаційні ігри: «Барометр професій», «Угадай професію»;

- години спілкування: «Калейдоскоп професій», «Усі професії важливі, усі професії потрібні»;

- тренінгові вправи «Карта інтересів», «Зроби вибір», «Знайди свій шлях», «Мій тип професії», «Шукаю роботу/ оголошення», «Професійний попит: специфіка регіону», «Рейтинг помилок», вправа-дискусія «Усвідомлений вибір професії», тощо;

- ділова гра: «Моя майбутня професія»;

- диспут: «Кар'єра чи кар'єризм?», «У пошуках ідеальної професії, або що про це думають у світі?», тощо.

Наведемо приклад тренінгових вправ, запропонованих науковцями Т. Лях, Ю. Малієнко, Н. Троценко, Т. Цюман, А. Шеламкова [8], які доцільно використовувати в школі.

Вправа «Мій герб». Протягом 15 хв. ведучий пропонує учасникам створити власний герб, до змісту якого входять ім'я, життєве кредо, хобі, здібності, таланти, захоплення, інтереси. Ведучий на ватмані презентує схему розробки герба та наголошує на тому, що герб має якнайповніше представити господаря. Лише віконце «думка друзів» заповнюватиметься через деякий час.

По закінченню роботи учасники влаштовують геральдичне зібрання, прикріплюючи власні герби на дошку.

Ведучий роздає кожному учаснику по 3 клейкі аркуші та пояснює суть наступного етапу вправи: «Ви зараз маєте можливість познайомитись з унікальними експонатами - гербами ваших однокласників. Детально розгляньте кожний 3 них, проаналізуйте заявлені автором герба власні чесноти. У разі, якщо автор щось важливе про себе не зазначив, то підкресліть / зазначте не вказану ним чесноту, записавши ii (ix) на клейкому аркуші та прикріпивши у відповідному віконечку «Думка друзів». На цю роботу групі відводиться 10 хв. [8, с. 18].

Вправа «Ярмарок рівних можливостей». Ведучий представляє членів комісії та оголошує процедуру проведення ярмарку. Звертає увагу учасників на те, що на дошці розміщено перелік професій, з яким учасники вправи мають ознайомитися.

На наступному етапі учасники презентують свої візитки, а комісія оцінює презентації кожного учасника та висловлює свої рекомендації щодо обрання майбутньої професії [8, c. 20].

Профільне навчання, до якого перейшла останнім часом старша загальноосвітня школа, має бути спрямоване на забезпечення розгортання індивідуальної освітньої 
траєкторії старшокласника, і потребує наявності цілеспрямованої, організованої системи профорієнтаційної роботи. Проте, нині вона ще має безсистемний, епізодичний, іноді формальний характер. Тому систематичне використання різноманітних форм та методів профорієнтаційної роботи має здійснюватися за спільних зусиль школи, сім’ї та ВНЗ.

Перспективу подальших досліджень убачаємо у визначенні педагогічних умов формування професійної спрямованості старшокласників.

\section{Література}

1. Адаменко О. В. Проблеми диференційованого i профільного навчання у вітчизняній педагогіці другої половини XX століття / О.В.Адаменко // Наук. зап. Сер. Педагогіка і психологія / Вінниц. держ. пед. ун-т ім. М. Коцюбинського. Вінниця, 2004. - № 11. - С. 68-72. 2. Браташ О. Проблеми і розвиток вищої гірничої освіти [Електронний ресурс]/ О. Браташ. - Режим доступу: http://ea.dgtu.donetsk.ua:8080/jspui/ bitstream/ 123456789/ 7279/1 3. Коломісць М. Проблема підготовки класного керівника до організації профорієнтаційної роботи / М. Коломієць // Проблеми підготовки сучасного вчителя: наук.-метод. зб. - Умань, 2013. - № 7. - С. 176-182. 4. Концепція державної системи професійної орієнтації населення [Електронний ресурс].- Режим доступу: http://zakon4.rada.gov.ua/laws/show/842-2008 5. Мантуленко С. В. Формування готовності майбутніх учителів географії до профільного навчання старшокласників: дис. ... канд. пед. наук: 13.00.04 / Світлана Вікторівна Мантуленко. - Кривий Ріг, 2014. - 253 с. 6. Побірченко Н. А. Організаційно-психологічні умови професійної орієнтації в загальноосвітній школі / Н. А. Побірченко, І. Б. Марченко // Проблеми сучасної психології: зб. наук. праць К-ПНУ імені Івана Огієнка, Інститут психології ім. Г. С. Костюка АПН України - 2009. - Вип. 6.- Ч. 2. - С. 175-185. 7. Положення про професійну орієнтацію молоді, яка навчається // Інформаційний збірник Міністерства освіти України. - К. 1995. - № 15. - С. 2-7. 8. Професія. Кар’єра. Успіх / [Авториупоряд. : Лях Т. Л., Малієнко Ю. М., Троценко Н. Є., Цюман Т. П., Шеламкова А. М.]; за ред. Т. П. Цюман. - К. : Основа-Принт, 2010. - 132 с. 9. Профільне навчання в старшій школі: шляхи розвитку: [наук.-доп. бібліогр. покажч.]. Вип.1/ АПН України. ДНПБ України ім. В. О. Сухомлинського; уклад.: Л. О. Пономаренко, Л. І. Ніколюк, Л. І. Самчук, I. М. Каневська [Електронний ресурс]. - К., 2004. - 163 с. - Режим доступу: http://www.dnpb.gov.ua/ datas/upload/files/320849870.pdf

УДК 373.55.016:91

Ірина Варфоломеєва

\section{ОРГАНІЗАЦІЯ НАВЧАЛЬНО-ВИРОБНИЧОЇ ПРАКТИКИ У КЛАСАХ ГЕОГРАФІЧНОГО ПРОФІЛЮ}

Варфоломєєва I. М. Організація навчально-виробничої практики $\quad$ у класах географічного профілю.

У статті подано теоретичне обгрунтування проведення літньої навчальної практики з географії в умовах старшої профільної школи та методичні рекомендації $з$ удосконалення і впровадження у практику теоретичних основ іiі організації у 10 класах географічного профілю.

Ключові слова: профільне навчання, навчально-виробнича практика, географічний профіль, педагогічна практика, географія.

Варфоломеева I. М. Организация учебно-производственной практики в классах географического профиля. 